\title{
Effect of thinning on flower and fruit and of edible coatings on postharvest quality of jaboticaba fruit stored at low temperature
}

Talita Pimenta do NASCIMENTO ${ }^{1}$, José Emílio BETTIOL NETO², Renato Alves PEREIRA², Inar Alves de $\mathrm{CASTRO}^{1}$, Edvan Alves CHAGAS ${ }^{4}$, Franco Maria LAJOLO ${ }^{1}$, Beatriz Rosana CORDENUNSI ${ }^{1 \star}$

\begin{abstract}
Jaboticaba is a Brazilian fruit, native to the Atlantic forest, which belongs to the Myrtaceae family. In this work we describe the effect of the thinning of "flower", "fruit" and "flower \& fruit" compared to non-thinned fruit (control) and of edible coatings with respect on nutritional composition, overall acceptability and shelf-life of jaboticaba 'Sabara', grown in an irrigated commercial orchard. "Flower and fruit" thinning allows fruit with higher quality as diameter, volume and mass. Non-thinned fruit shows higher yield, however fruit have lower quality. As a result of the improving quality at harvest, the shelf life was twice ( $\sim$ days) for thinned fruit. The lack of change in concentration of soluble sugar and absence of formation of volatile compounds during storage indicate that there was no natural fermentation of the jaboticaba pulp after harvest. Treatments with wax and calcium did not improve the jaboticaba shelf life.
\end{abstract}

Keywords: jaboticaba Sabará; soluble sugars; shelf life; organic acids.

\section{Introduction}

The jaboticaba is a common Brazilian fruit found in the Atlantic forest, which belongs to the Myrciaria genus (Myrtaceae family). This genus includes a number of species such as M. jaboticaba, M. peruviana, M. cauliflora, and M. aureana. Myrciaria jaboticaba (Vell) O. Berg is commonly known as Sabara and it is the most productive, appreciated and cultivated species within the genus (MANICA, 2000).

These species are found mainly in the South and Southeast states of Brazil, in regions where the climate is suitable for extensive cultivation (SOARES et al., 2001). Jaboticaba fruit typically takes $40-46$ days to reach maturity and grows directly from the stem (Figure 1). When mature, it is a globular, small fruit $(\sim 1.4 \mathrm{~cm})$. The fruit has a thick resistant, dark purple skin and a juicy and sweet pulp containing 2 to 4 seeds (depending on the species). It is mainly consumed fresh but is also made into jams, liqueurs, wines and vinegar (DONADIO; MÔRO; SERVIDONE, 2004).

Jaboticaba is composed of an average of $88 \%$ moisture, $9 \%$ carbohydrates, 2\% dietary fiber and low levels of protein and lipid (UNIVERSIDADE..., 1998). Although not often consumed, the jaboticaba skin was the subject of several researches because of the high content of anthocyanins (MONTES et al., 2005). In this way, Reynertson et al. (2006) found tannins, cyanidin 3-glucoside and a new depside, jaboticabin in M. cauliflora, as part of their studies with antioxidants and cancer chemopreventive compounds from tropical fruit.
Jaboticaba has commercial potential due to its flavor and appearance but is distributed on a small scale due to its high spoilage, which hinders fruit production and quality. Because of this, marketing to the more distant states of Brazil as well as exportation are greatly hampered.

The jaboticaba postharvest life is very short ( 4 days), mainly because of the rapid loss of water, which causes changes in the texture of the fruit. In addition, the skin loses luster and the taste changes drastically. It is thought that this change in taste may be caused by a fermentation process in the pulp that begins as soon as the fruit is picked (BARROS; FINGER; MAGALHÃES, 1996).

Pre- and postharvest techniques such as flower and fruit thinning and application of edible coatings, can be an alternative to extend shelf life and maintain the fruit quality. The edible coating acts as a barrier against the transport of gases and can reduce the fruit water loss to the environment, lowering the wilting of the fruit which is the main factor of deterioration of display jaboticaba quality. So, when the metabolism is slowed, the moisture transfer and loss of flavor are reduced, improving the overall appearance of the fruit and retards senescence during natural storage (VARGAS et al., 2008; ESPINO-DÍAS et al., 2010). Thinning practices eliminate some of the flowers and/ or fruit to enhance fruit quality remnants. The main goal of thinning is to increase fruit size because the smaller number of the fruit on the plant reduces competition for photosynthates,

${ }^{1}$ Department of Food Science and Experimental Nutrition, FCF, University of São Paulo - USP, Av. Lineu Prestes, 580, Bloco 14, CEP 05508-900, São Paulo, SP, Brazil, e-mail: hojak@usp.br

2 Instituto Agronômico de Campinas - IAC, Av. Barão de Itapura, 1481, Guanabara, CEP 13020-430, Campinas, SP, Brasil

3 Escritório de Desenvolvimento Rural de Mogi das Cruzes, Coordenadoria de Assistência Técnica Integral - CATI, Av. Cândido Xavier de Almeida e Souza, 35, Centro Cívico, CEP 08780-210, Mogi das Cruzes, SP, Brasil

${ }^{4}$ Empresa Brasileira de Pesquisa Agropecuária - EMBRAPA, Embrapa Roraima, Rod. BR 174, Km 8, CP 133, CEP 69301-970, Boa Vista, RR, Brasil

${ }^{*}$ Corresponding author 

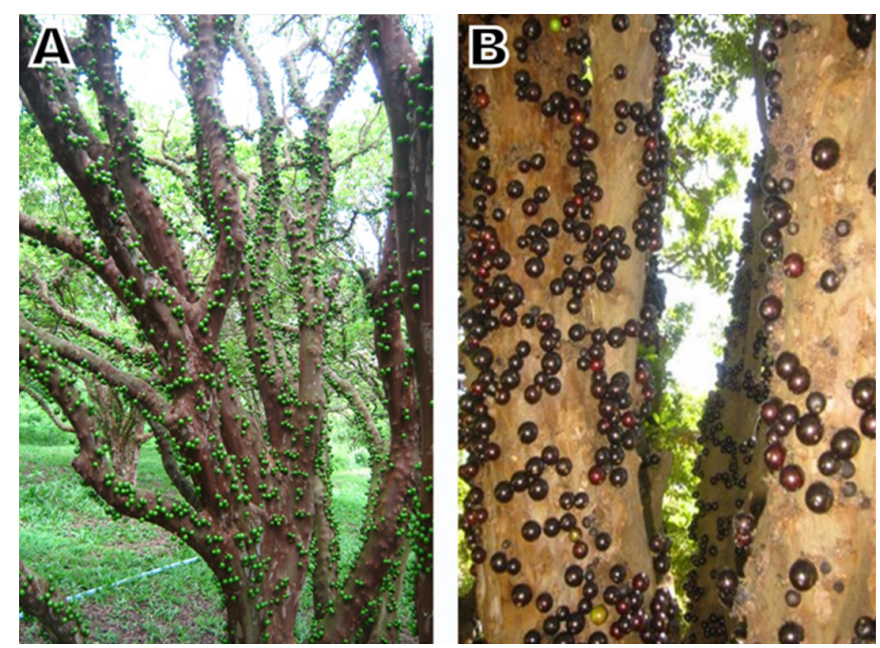

Figure 1. (A) Orchard with developing jaboticaba (B) Jaboticaba tree branches covered with mature, ripe fruit.

minerals, water and other compounds (TONIETTO et al., 2000). It prevents limb breakage due to excess of weight and reduces alternate bearing that is caused by fruit overproduction, which would bring about low yield in the following year (OUMA, 2012; HEHNEN et al., 2012).

In addition to benefits in fruit, thinning allows the plant optimum vegetative growth due to efficient nutrient input and greater resistance to insect infestation and diseases. Fallahi and Mohan (2000) also emphasize the existence of other factors on fruit quality, as cultivated species, mineral nutrition, soil properties, climatic factors, cultural practices, among others.

The goal of this work was to extend the jaboticaba shelf life through pre- and postharvest treatments. Three approaches were used to achieve this goal to improve the quality and the shelf life of jaboticaba fruit: (1) in the field, flowers and/or fruit were thinned in order to improve fruit size, mass and uniformity, and (2) after harvest, fruit were stored at a low temperature in packages both with and without potassium permanganate sachets (ethylene oxidant) and, (3) jaboticaba peels were covered by calcium chloride or wax.

\section{Materials and methods}

\subsection{Plant material}

The experiment was conducted in 2008, in a commercial orchard irrigated of plants of M. jaboticaba (Vell.) Berg species cv. Sabará, planted at $7 \times 7$ meters, in Guararema (São Paulo, Brazil). During the productive cycle 2008/2009, were made all the cultural practices needed for the crop. To reduce the competition between weeds and Jaboticaba plants were performed, annually, mechanical weeding with mowing and weeding among plants rows, besides the glyphosate herbicide application, alternately. Liming was performed with slight lime incorporation aiming to raise the orchard-soil base saturation to $70 \%$. Fertilization was carried out to improve the nutritional requirements of the plants, according to recommendations for the crop. We used $1.5 \mathrm{~kg}$ of 04-14-08 formula in January 2008 and the same amount of fertilizer in July 2008 per plant. Later, there were more than two applications of $1 \mathrm{~kg}$ formula $10-10-10$ per plant. For pests and diseases control were made fortnightly sprays on test plants, with rotation of fungicides and insecticides recommended for the biological agent.

The jaboticaba plant orchard was subjected to four different treatments of thinning: 1) Control - no flower or fruit thinning; 2) Flower thinning; 3) Fruit thinning; 4) Flower and fruit thinning.

The process of thinning was done manually. (1) For flower thinning, a brush was lightly passed over the branches. This was done when they had flowers lacking stamens and petals at the beginning of drying. A hair brush was used on the dorsal and ventral branches to remove any existing flowers found within 50 centimeters of the terminal branches. (2) For the "flower and fruit" thinning, after 21 days of the flower thinning, the remaining fruit that reached an average of $5 \mathrm{~mm}$ in diameter was manually removed ("flower and fruit" thinning). (3) For fruit thinning, after 21 days of flowering, a number of fruit were removed from the branches. All the fruit growing in $50 \mathrm{~cm}$ of terminal branches were also eliminated. For the control, there was no intervention in the flowering and / or fruiting. The tested areas were cultivated in the same way as the other plants in the orchard. Each treatment contained four plants (each plant produces on average $200 \mathrm{~kg}$ fruit).

The phenological stages were monitored weekly during reproductive development and, at each stage, the fruit diameter, volume and mass were evaluated. At the harvest time, all the variables mentioned above were evaluated again, including the yield per plant.

The diameter was measured with a digital caliper. Fruit size was measured by the conversion into unit volume of each fruit, which was calculated from the average diameter, measured using a caliper. The volume was obtained by the formula: Volume $=4$ / $3^{*} \mathrm{pi}^{\star} \mathrm{r} 3$, where: $\mathrm{PI}(\pi)=3.1415926535, \mathrm{r}=$ mean radius.

The mass was measured with an electronic scale. The estimative yield per plant was calculated by measuring the diameters of the four plants branches, and subsequently calculated the yield area, considering the branches of cylindrical shape. The calculation basis for each treatment was the average fruit mass, making four replicates per treatment, whereas samples collected in an area equivalent to 1 meter of branch.

Mature fruit were stored in cardboard boxes at $6{ }^{\circ} \mathrm{C}$ and $90 \%$ RH both with and without potassium permanganate sachets (27 boxes; 25 fruits per box). Each day, some fruit were skinned, and the pulp (without the seeds) was frozen in liquid nitrogen for later analysis. Sample frozen consists of $700 \mathrm{~g}$ or 140 fruit for each treatment.

\subsection{Coating solution treatment}

This experiment was performed with fruit not subjected to thinning. The wax solution was prepared by dissolving $20 \%$ carnauba wax, Megh Wax ECF 124, in distilled water. The coating treatment was applied by quick dipping fruit into the solution. The $4 \%$ calcium chloride solution was prepared in 
distilled water. The coating treatment was applied by dipping fruit into the solution for 40 minutes. Then, fruit were dried at room temperature. Control fruit were subjected to water treatment. Fruit were conditioned in polystyrene terephthalate trays and wrapped with $14 \mu \mathrm{m}$ polyvinyl chloride film, and stored at $6{ }^{\circ} \mathrm{C}$ and $90 \% \mathrm{RH}$ for up to 7 days.

\subsection{Carbohydrate content}

Soluble sugars were extracted in three portions of $80 \%$ (v/v) ethanol at $80^{\circ} \mathrm{C}$. After centrifugation, the supernatant was collected, and the procedure was repeated twice. The filtrates were combined, the ethanol was evaporated under vacuum and the volume was reconstituted with water. Soluble sugars were analyzed by high pressure liquid chromatography coupled with pulsed amperometric detection (HPLC-PAD - Dionex, Sunnyvale, CA, USA) using a CarboPac PA (Dionex, Sunnyvale, CA, USA) and an isocratic run in $\mathrm{NaOH} 18 \mathrm{mM}$ for 25 minutes (CORDENUNSI et al., 2005).

\subsection{Organic and ascorbic acids contents}

The organic acid extraction of the samples was performed in triplicate using distilled water in a 1:4 ratio. The sample was processed in a Potter type homogenizer for 1 minute (on ice bath) and centrifuged at 10,000 $\mathrm{g}$ for 10 minutes at $4{ }^{\circ} \mathrm{C}$. The organic acids in the supernatant were analyzed by HPLC-DAD, according to the method used by Amorós et al. (2003). The ascorbic acid levels were determined as described by Cordenunsi et al. (2005). Total ascorbic acid was extracted with metaphosphoric acid (6\%) and analyzed by reverse phase HPLC in a Hewlett-Packard 1100 system coupled to a diode array detector (DAD) G1315A.

\subsection{Sensorial analysis}

Overall acceptability of the jaboticaba samples was evaluated using a nine point hedonic scale, where 1 was designed as "dislike extremely" and 9 as "like extremely". Forty untrained tasters were recruited from the University staff based on the interest and jaboticaba consuming habits. Samples were washed and served in a white receptacle identified with 3 digits. The tasters were in individual booths. The two samples, "flower and fruit" thinning and control (packed with and without potassium permanganate sachets), were presented in two orders ("flower and fruit" thinning - control and control - control) the same number of times. The tasters were instructed to identify which attribute of the fruit (color, texture, odor or flavor) had the strongest influence on the acceptability score. The results were evaluated with a normality test (Shapiro Wilk) and were statistically analyzed by the non-parametric Mann-Whitney test, using a value of $5 \%$.

This work was approved by the Research Ethics Committee - University of São Paulo - Pharmaceutical Sciences Faculty - Protocol CEP 484.

\subsection{Volatile aroma capture}

Jaboticaba fruit and smashed pulp were enclosed in separated jars, and a solid phase microextraction fiber (DVB/
CAR/PDMS - SUPELCO Bellefonte, PA) was used to capture the volatile aromatic compounds present in the headspace for 3 hours at $30{ }^{\circ} \mathrm{C}$. The fiber containing the volatile aromatic compounds was injected into a GC-MS system.

Volatile aromatic compounds were analyzed using a gas chromatograph HP 6890 (Hewlett Packard) interfaced with an HP 5973 mass spectrometer (Hewlett Packard) with electron impact ionization $(70 \mathrm{eV})$. A SUPELCOWAX-10 capillary column (30 m×0.25 mm, $0.25 \mu \mathrm{m}$ film thickness - SUPELCO) was used to separate the compounds. The oven temperature was programmed to rise from $50{ }^{\circ} \mathrm{C}$ to $150{ }^{\circ} \mathrm{C}$ at a rate of $2{ }^{\circ} \mathrm{C} / \mathrm{min}$ and helium was used as carrier gas with a flow rate of $1.0 \mathrm{~mL} / \mathrm{min}$; splitless mode was used. Scan time and mass range were $5.19 \mathrm{~s}$ and $30-550 \mathrm{~m} / z$, respectively.

\subsection{Scanning electron microscopy (SEM)}

The surfaces of the jaboticaba-control fruit skin, cv. Paulista and Rajada, and fruit treated with $20 \%$ wax were examined by SEM. Small sections of the rind were excised with a razor blade. Samples were fixed on aluminum stubs with doublesided carbon tape and the analysis were conducted in Electron Microscopy FEI brand, model Quanta 600 FEG. The images were obtained from secondary electrons, low vacuum mode, operating at $10 \mathrm{kV}$.

\subsection{Statistical analysis}

The study consisted of a randomized block statistical design, with four replications. Data were subjected to analysis of variance using the program OriginPro 8.0 SR0 (OriginLab Corporation, MA, USA). Means were compared by Tukey's test at $5 \%$ probability and were submitted to linear regression analysis (GOMES, 2000).

\section{Results and discussion}

\subsection{Phenological and thinning characteristics}

The productive cycle was classified into ten phenological stages that can be visualized in Figure 2. The color changes in Jaboticaba fruit started at the third stage when the largest fruit were about $17 \mathrm{~mm}$. Color changes process occurred in a continual manner until stage 9 when the fruit had intense black color. Seven days after reaching this stage, fruit were already completely shriveled and often rotten. The commercial harvest occurs between the 8 and 9 stages and, and in the present work the crop was harvested at stage 9 when fruit had an intense black color.

Fruit from "flower and fruit" thinning showed the best results for diameter, volume, and fruit mass between treatments. The diameter had increased between 8 and 9 stages, decreasing afterwards (Figure 3A). Thinning treatment aims to uniform fruit size, as well as to ensure fruit with suitable diameters for market standard (PERIN et al., 2012). Except for the "fruit thinning", the diameters of the fruit that suffered the thinning treatments were greater than the control. The volume showed a continual growth between stages 9 and 10, reaching 
$4476.04 \mathrm{~mm}^{3}$ (Figure 3B). The second best result was obtained when plants were subjected to "flower thinning" and "fruit thinning". These results confirmed the beneficial effect of this practice in an orchard, thus favoring an improved fruit size. Probably, thinning during the full bloom period allows higher amount of reserves for the remaining buds and better physiological structure. In addition to the positive effect of flower thinning, we observed positive effect of an additional fruit thinning. This result was similar to obtained by Bernardi and Hoffmann (2003), who reported that the better peach fruit quality response to thinning occurred when it was performed during the period from flowering to 30 days after petal drop.

The thinning treatment significantly influenced the fruit mass. For "flower and fruit" thinning treatment, there was a linear increase in fruit mass with advancing development stages (Figure 3C). The lowest fruit mass was observed in the controlfruit where fruit showed a growth between 8 and 9 stages and reached mass of $4.42 \mathrm{~g}$ (Figure 3C). The set of results obtained with the "flower and fruit" thinning indicates that the harvest

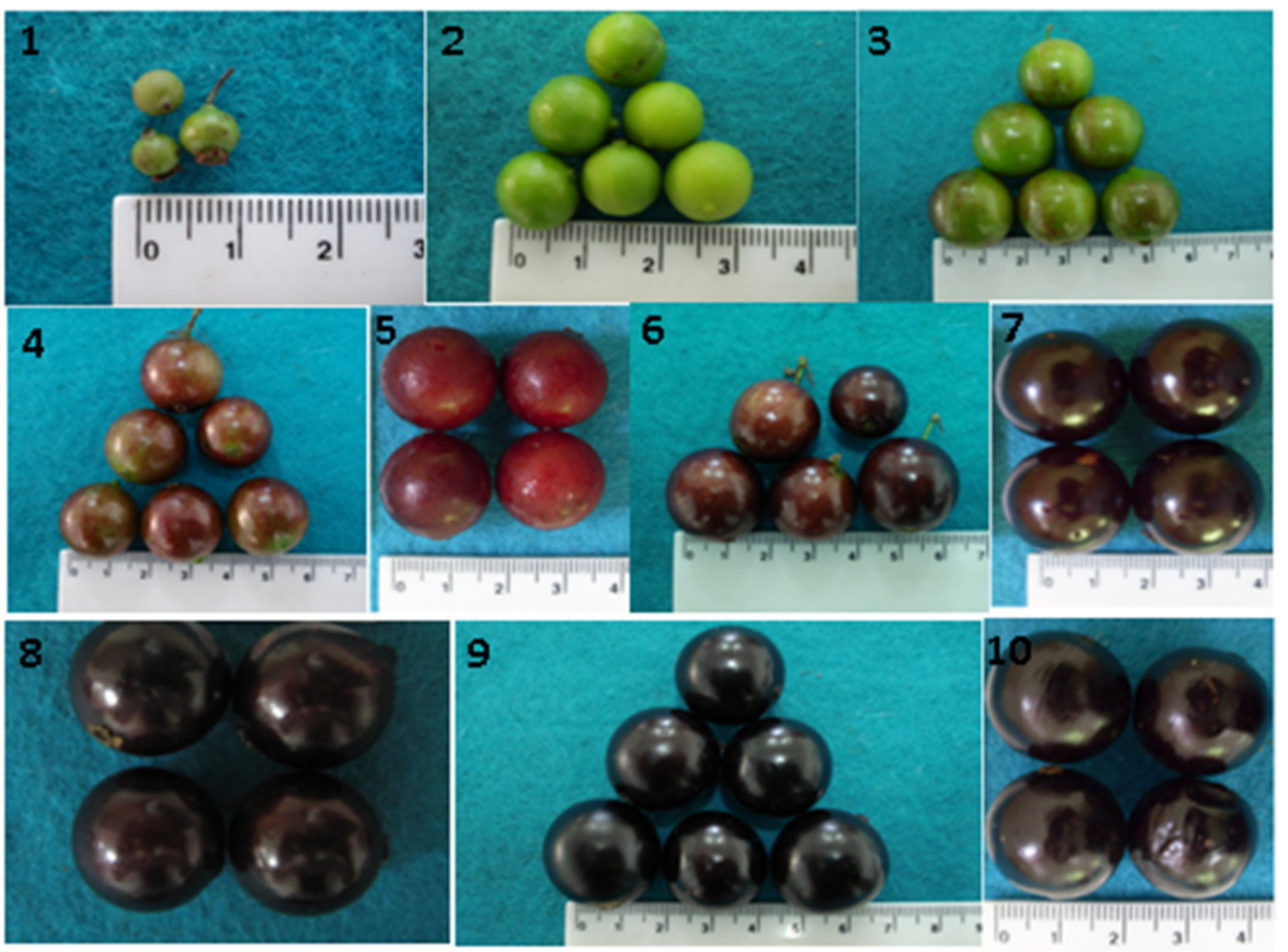

Figure 2. Illustrative images of Jaboticaba fruits evaluated during the various stages in the cycle 2008/2009 (1 - Berries with floral remains, 2 - Whitening fruit, 3 - Beginning of fruit color, 4 - Fruit painted, 5 - Red fruit, 6 - Intense red fruit, 7 - Black fruit, 8 - Intense Black fruit, 9 - Fruit at the point of harvest, 10 - Ruddy fruit).

Table 1. Diameter, volume, mass and fruit yield of jaboticaba Sabara tree subjected to different treatments of thinning, at the time of commercial harvest.

\begin{tabular}{|c|c|c|c|c|}
\hline Treatments & $\begin{array}{c}\text { Diameter }^{1} \\
\mathrm{~cm}\end{array}$ & $\begin{array}{c}\text { Mass }^{1} \\
\mathrm{~g}\end{array}$ & $\begin{array}{c}\text { Volume }^{1} \\
\mathrm{~mm}^{3}\end{array}$ & $\begin{array}{c}\text { Yield }^{1} \\
\text { kg.plant }\end{array}$ \\
\hline Control $(n=130)$ & $1.40 \pm 0.12^{c}$ & $3.86 \pm 1.58^{\mathrm{d}}$ & $1932.24 \pm 191.50^{c}$ & $227.20 \pm 27.36^{\mathrm{a}}$ \\
\hline Flower thinning $(\mathrm{n}=75)$ & $1.62 \pm 0.10^{\mathrm{ab}}$ & $5.08 \pm 0.84^{\mathrm{c}}$ & $2719.73 \pm 513.09^{b}$ & $119.58 \pm 14.40^{\mathrm{bc}}$ \\
\hline Fruit thinning $(\mathrm{n}=86)$ & $1.73 \pm 0.33^{\mathrm{b}}$ & $5.68 \pm 1.20^{\mathrm{b}}$ & $3165.27 \pm 51.79^{\mathrm{b}}$ & $106.50 \pm 12.83^{c}$ \\
\hline Flower and fruit thinning $(n=66)$ & $2.21 \pm 0.20^{\mathrm{a}}$ & $10.31 \pm 1.65^{\mathrm{a}}$ & $5674.16 \pm 146.74^{\mathrm{a}}$ & $125.93 \pm 15.17^{\mathrm{b}}$ \\
\hline
\end{tabular}

${ }^{1}$ Means in the same column followed by the same letter are not significantly different by Tukey's test at $5 \%$ level of probability. 
can be made between stages 7 and 8 , rather than stages 8 and 9 , as have been done nowadays. This procedure may increase the shelf life of jaboticaba, but further studies should be developed before a recommendation to the jaboticaba producers.

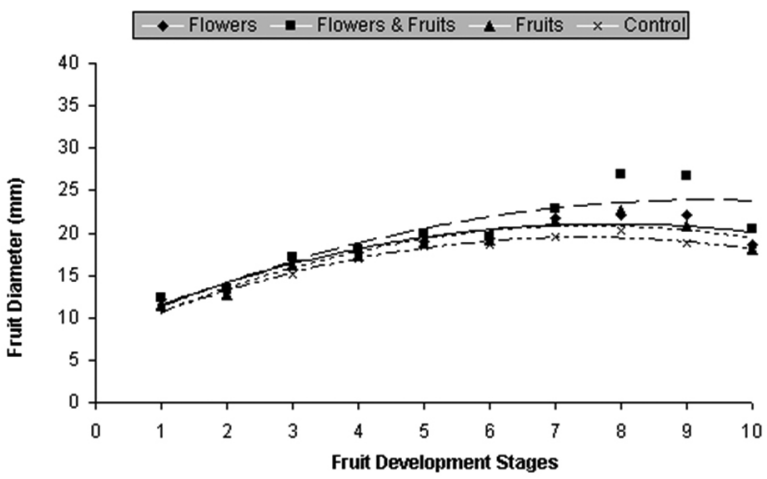

A
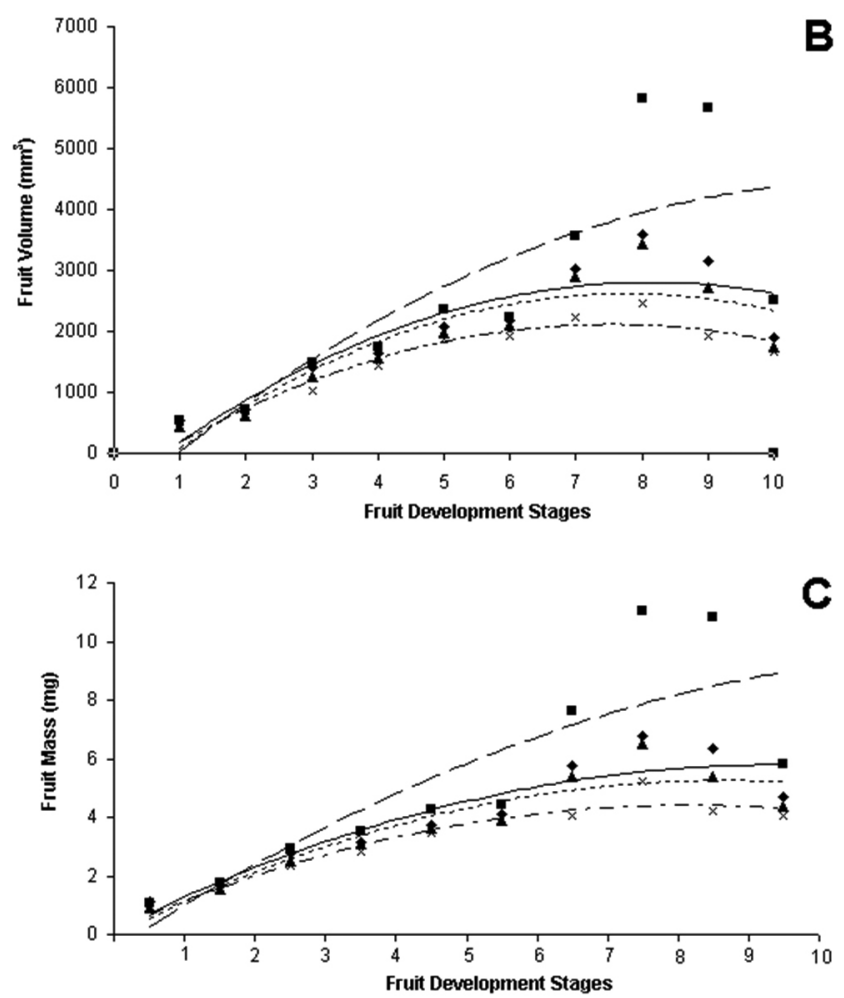

Figure 3. Diameter (A), volume (B) and mass (C) of Jaboticaba fruit subjected to hand thinning at various stages ( 1 - Control, no flower or fruit thinning; 2 - Flower thinning; 3 - Fruit thinning; 4 - Flower and fruit thinning) of development. Diameter: yFlower $=-0.2075 x 2+3.2358 x+8.4902$ $\mathrm{R} 2=0.92 ; \mathrm{yFlower}$ and Fruit $=-0.1835 \mathrm{x} 2+3.414 \mathrm{x}+8.0385$ $\mathrm{R} 2=0.82 ;$ yFruit $=-0.2398 \mathrm{x} 2+3.6159 \mathrm{x}+7.2207 \mathrm{R} 2=0.93$; $\mathrm{yControl}=-0.2136 \mathrm{x} 2+3.1739 \mathrm{x}+7.7167 \mathrm{R} 2=0.9779$; Volume: $y$ Flower $=-51.473 \times 2+837.63 \mathrm{x}-601.24 \mathrm{R} 2=0.80^{*}$; yFlower and Fruits $=-38.923 \times 2+909.96 \mathrm{x}-843.03$ $\mathrm{R} 2=0.65^{*}$; yFruit $=-55.494 \times 2+862.28 \mathrm{x}-731.63$ $\mathrm{R} 2=0.82^{*} ; \mathrm{yControl}=-45.217 \mathrm{x} 2+681.38 \mathrm{x}-450.85$ $\mathrm{R} 2=0.93^{*}$; Mass: $\mathrm{yFlower}=-0.063 \mathrm{x} 2+1.257 \mathrm{x}-0.470$ $\mathrm{R}^{2}=0.87$; yFlower and Fruit $=-0.060 \mathrm{x} 2+1.631 \mathrm{x}-1.319$ $\mathrm{R}^{2}=0.72 ;$ yFruit $=-0.070 \mathrm{x} 2+1.297 \mathrm{x}-0.688 \mathrm{R}^{2}=0.87$; $\mathrm{yControl}=-0.064 \mathrm{x} 2+1.108 \mathrm{x}-0.382 \mathrm{R}^{2}=0.94$.
Table 1 shows an overview of the Jaboticaba fruit diameter, mass and yield for various thinning treatments at the time of commercial harvest. For all the variables, the best results were obtained when the plants were subjected to "flower and fruit" thinning, except in the control-fruit with higher yield.

The yield of "control-fruit" was around $227 \mathrm{~kg}$. plant ${ }^{-1}$, followed by "flower and fruit" thinning $\left(\sim 125 \mathrm{~kg}\right.$. plant $\left.{ }^{-1}\right)$ and "flower thinning" ( 119 kg. plant $\left.{ }^{-1}\right)$ (Table 1). The yield of the control-fruit was $47 \%$ higher than the best result in thinning treatments, "flower and fruit" thinning. It was noted also that the largest fruit diameter, volume and mass at harvest in the "flower and fruit" thinning have not contributed to increased yield in this treatment (Table 1). Probably, the greatest yield on control-fruit arose from the greater amount of fruit harvested (data not shown). However, the lower yield on "flower and fruit" thinning may be offset by the higher price paid per kilogram of the fruit at time of sale ( $\sim 4$ times more).

Jaboticaba of the control-fruit group had fungal growth prior to harvest, even in the tree (Figure 4A). In addition, an increased number of control fruit were deformed because of the excessive number of fruit growing in the same space. This crowding caused stem disruption, promoting rot and secondary infections.

As similarly observed in other fruit, in addition to temperature, wetness between fruit also plays a key role in the establishment of infections (Figure 4B/C). Schwabe (1982) reported that the period of humidity necessary for infection with Venturia inaequalis fungus in apple fruit is greater than required in the leaves, and increases as development progresses. In guava, the pathogen Puccinia psidii is detected after at least eight hours of wetness (SOUZA FILHO; COSTA, 2003). Puccinia psidii is a fungus that causes severe disease in jaboticaba trees (SOARES et al., 2001). It is likely that the best results observed in the thinning treatments are related to the reduction in the humidity in the spaces between fruit, because large physical distance between fruit promotes faster evaporation of water contained between thereof. Additionally, Bernardi and Hoffman (2003) reported that in peach, thinning improved the efficiency of chemical protection in fruit orchards, and consequently the quality.

\subsection{Shelf-life determination}

The temperature of postharvest storage was previously set by using control fruit. The temperatures $20^{\circ} \mathrm{C}, 12^{\circ} \mathrm{C}$ and $6^{\circ} \mathrm{C}$ were evaluated to ascertain the most appropriate condition for fruit storage. Samples stored at $12^{\circ} \mathrm{C}$ and $6^{\circ} \mathrm{C}$ lasted twice than those stored at $20^{\circ} \mathrm{C}$. Samples stored at $12^{\circ} \mathrm{C}$ weighed about $36 \%$ less than those stored at $6^{\circ} \mathrm{C}$ at 12 days of storage. Thus, the temperature of $6^{\circ} \mathrm{C}$ was chosen for further experiments.

The shelf-life of the control was four days, while the thinning treatments lasted twice. At the day 4, control fruit showed fungal growth, wrinkling and loss of skin brightness, becoming inappropriate for consumption, probably because of the initial fungal contamination (Figure 4A) and lower fruit quality. 

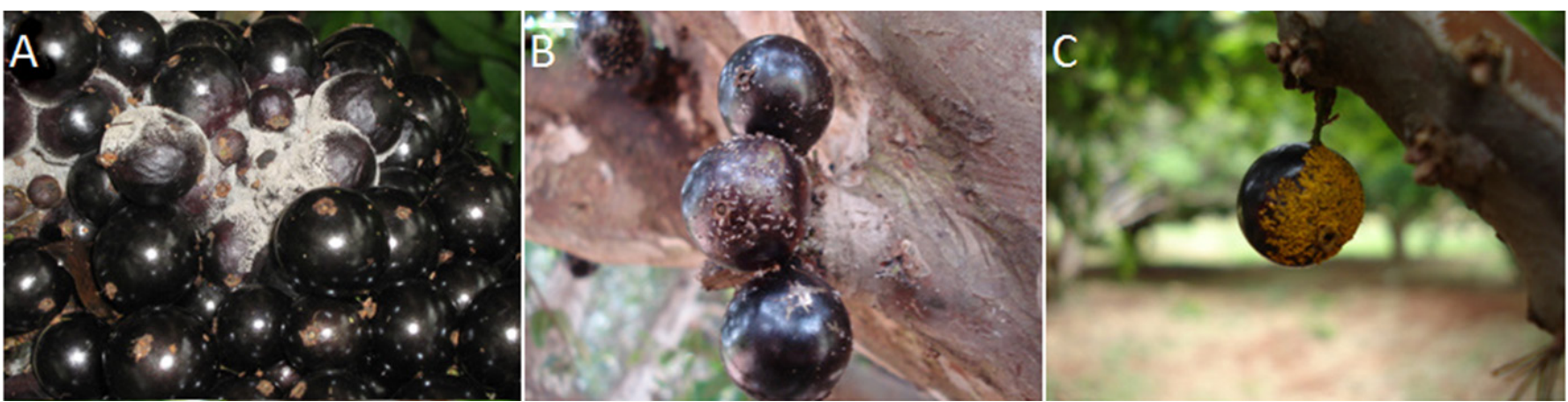

Figure 4. Pests and diseases incidence in Jaboticaba fruit in tree not subjected to thinning and deformation caused by the Jaboticaba fruit overproduction. Incidence of fungi (A), mealybugs (B) and rust (C).

Fruit stored with potassium permanganate sachets had the same shelf life as those stored without. Potassium permanganate is an ethylene oxidizing agent used in a sachet or directly on packaging. In some fruits (mostly climacteric), this sachet prevents the action of ethylene, which is released by the fruit during ripening. Blocking ethylene activity contributes to the maintenance of quality and extends the postharvest life of the fruit (ZAGORY, 1995). However, in jaboticaba, potassium permanganate had no influence in the weight loss: treatments with or without potassium permanganate sachet showed no differences in the weight loss (Figure 5). Similar effects were observed in mango and peach (BRACKMANN; STEFFENS; GIEHL, 2003; JERONIMO et al., 2007)

The aromatic volatiles were determined to elucidate the timing of the supposed fermentation process in jaboticaba. We looked for volatile compounds derived from the fermentative process such as butyric acid or ethanol. However, they were not detected in any stage of jaboticaba storage.

Total soluble sugar (TSS) was considered the sum of fructose, glucose and sucrose. All the treatments and control group produced fruit with more than $8 \mathrm{~g}$ TSS per $100 \mathrm{~g}$ pulp (Figure 6). Fructose was the predominant soluble sugar, followed by glucose or sucrose. Control fruit and thinning-treatments presented no differences to each other in terms of TSS as well as samples containing or not potassium permanganate sachet.

There was a little sucrose degradation during storage with a concomitant increase of monosaccharides (Figure 6). Total soluble sugars remained unchanged during storage in control fruit and thinning-treatments. Additionally, we found the same results for samples with and without potassium permanganate sachets.

It was not found ascorbic acid or dehydroascorbic acid in jaboticaba at any stage after harvest. Total organic acids amounts ranged from $1.77 \mathrm{~g} \cdot 100^{-1} \mathrm{~g}$ for flower thinning to $1.26 \mathrm{~g} \cdot 100^{-1} \mathrm{~g}$ for "flower and fruit" thinning (Figure 7). Independent of the treatment, at day 1 of storage, the predominant organic acid was the citric ( $64 \%)$, followed by malic $(\sim 19 \%)$ and succinic $(\sim 17 \%)$.

At days 4 and 8 , only citric acid was detected in all the treated samples. Organic acids are accumulated during fruit development and used as substrates in metabolic activities

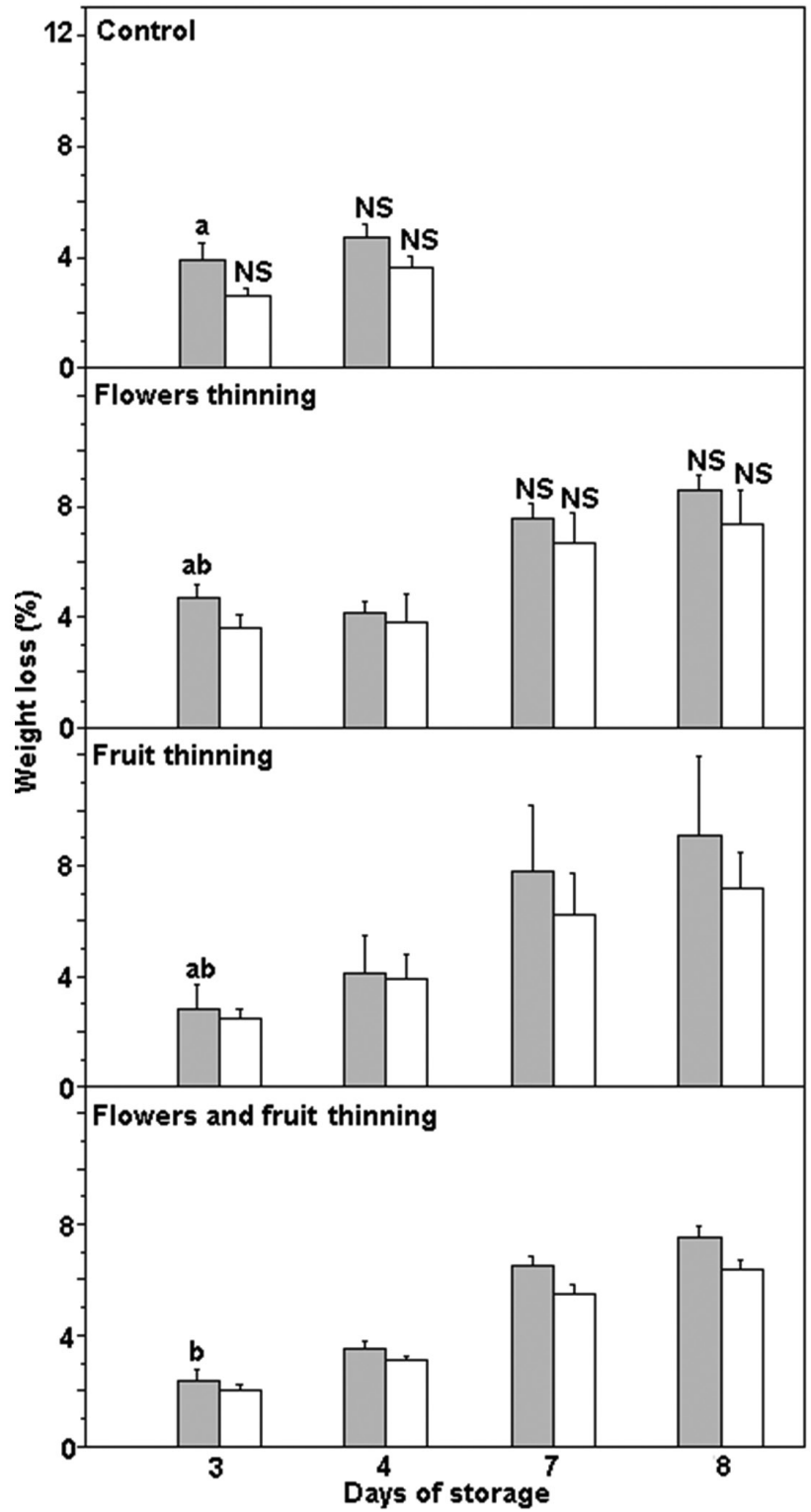

Figure 5. Weight loss of the jaboticaba 'Sabara' species, with ( $\square)$ or without sachet $(\square)$, stored at $6{ }^{\circ} \mathrm{C}$ for 8 days. Means in the same column followed by the same letter are not significantly different by Tukey's test at $5 \%$ level of probability. NS: No significant difference between treatments by Tukey's test. 


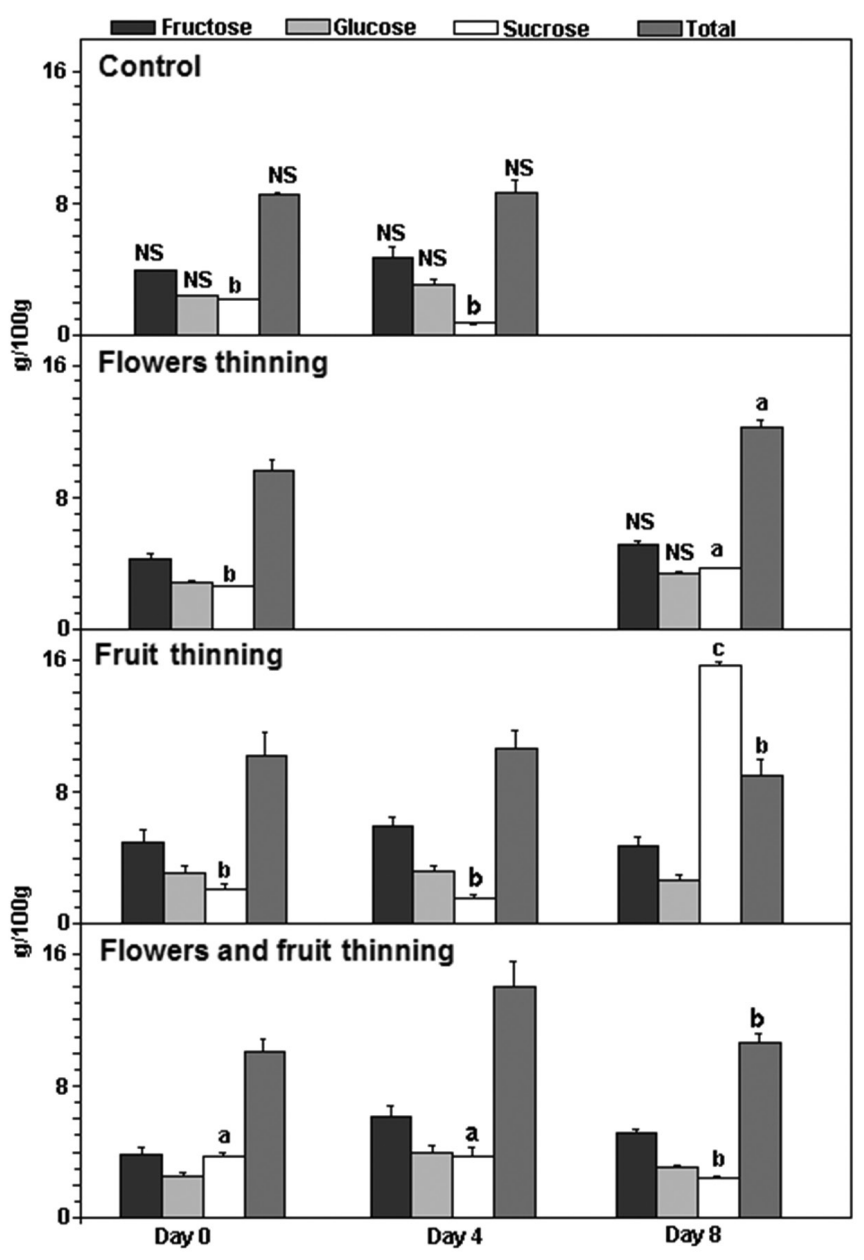

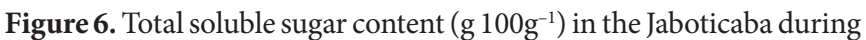
storage without potassium permanganate sachets. Means in the same column followed by the same letter are not significantly different by Tukey's test at $5 \%$ level of probability. NS: No significant difference between treatments by Tukey's test.

during ripening. Organic acids are consumed by the Krebs cycle during respiration and also are oxidized during gluconeogenesis, fermentation, anthocyanin synthesis, and amino acid interconversions (TAIZ; ZEIGE, 2009). In jaboticaba storage, there was a decline in citric acid levels in "control", "flower thinning" and "fruit thinning" samples, with or without potassium permanganate sachet. Citric acid concentrations in "flower and fruit" thinning, both with and without sachets, showed no variations in values during storage.

\subsection{Sensory analysis}

Initially, "flower and fruit" thinning and control samples were evaluated comparatively. Next, the permanganate effect was factored into the analysis. "Flower and fruit" thinning $(8.1 \pm 1.2)$ scored significantly higher $(\mathrm{p}<0.001)$ than control $(7.0 \pm 2.0)$. The sweet and sour flavors were the two attributes cited with higher frequency by the tasters of "flower and fruit" thinning and control samples, respectively. In control samples, both with and without potassium permanganate sachets, there was no difference in acceptability ( $\mathrm{p}=0.149)$ after 2 days of storage. Both

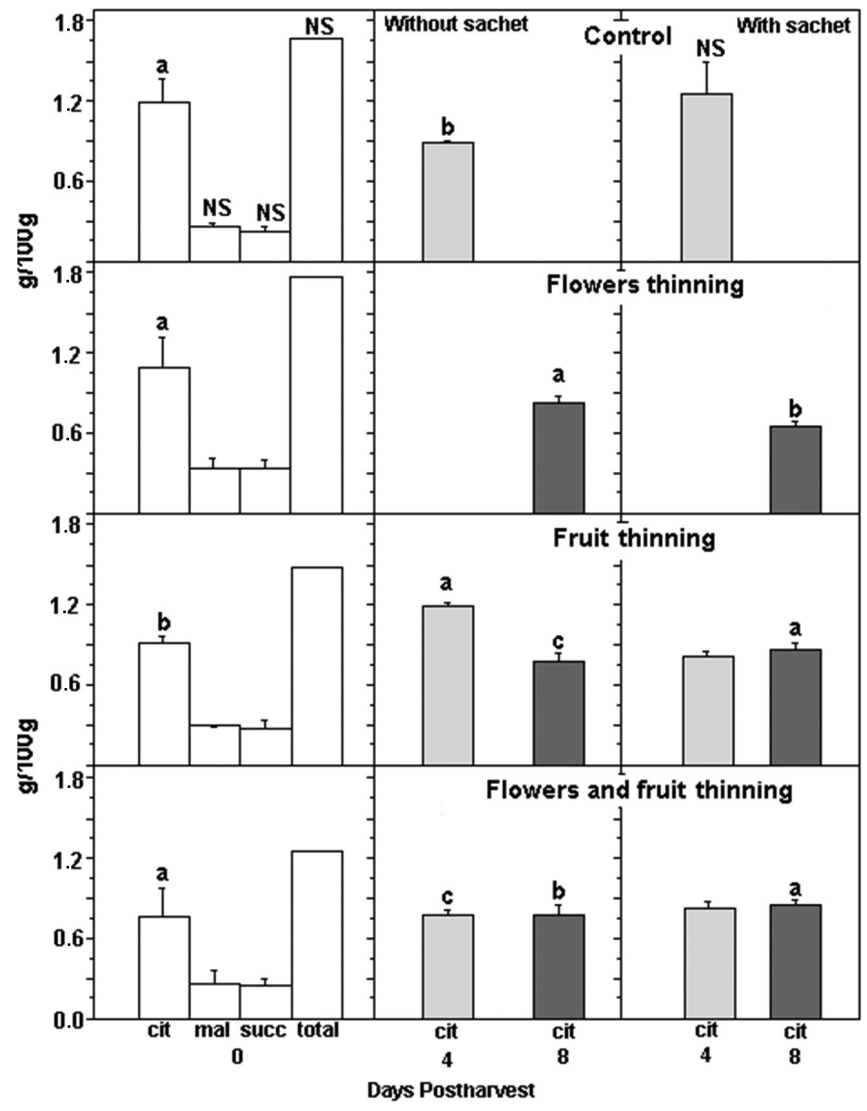

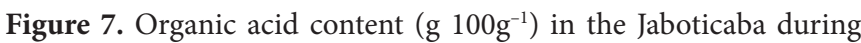
storage with and without potassium permanganate sachets. Cit (citric); mal (malic); succ (succinic). Means in the same column followed by the same letter are not significantly different by Tukey's test at $5 \%$ level of probability. NS: No significant difference between treatments by Tukey's test.

set of samples, with and without sachets, received acceptability scores of $7.0 \pm 1.5$ and $7.4 \pm 1.3$, respectively.

The same procedure was carried out using the "flower and fruit" thinning. After 5 days of storage, samples with and without potassium permanganate sachets obtained an acceptability score of $7.6 \pm 1.6$ and $7.5 \pm 1.6$, respectively. The acceptability score was not different between the samples $(\mathrm{p}=0.876)$. For both samples, flavor was the attribute with a greater influence on the tasters' responses.

\subsection{Shelf life tests with skin coating}

In a previous work (not published) we performed several tests, including shelf life test, in 5 cultivars of jaboticaba. There were differences in terms of weight loss and the consequent shelf life. The extremes were cv. Rajada that had higher dehydration, brightness loss and attack of pathogens and cv. Paulista that was one of the species with less weight loss.

Because of this result, we took images of skin surface by SEM searching for differences that could explain the higher permeability to the water of one cultivar over the others 
(Figure 8). The SEM images showed a thick layer of wax covering the surface of the cultivar with the lowest loss of water (Figure 8A - cv. Paulista), while the cultivar that lost more water was not entirely covered by a wax layer (Figure 8C - cv. Rajada). The skins surfaces were scraped to remove this layer, confirming their natural wax. Figures $8 \mathrm{~B}$ and $\mathrm{D}$ show what seems to be a removed layer of wax.

It is important to mention that the most resistant cultivar has the surface of the fruit skin covered with natural wax. And, if we covered the skin surface of the Sabara cultivar with extra wax, would the loss of water be reduced, thus extending shelf life? To respond this question, we decided to perform tests of shelf life reinforcing the wax from the skin surface of the $\mathrm{cv}$. Sabará with Carnauba wax.

Based on images obtained from the jaboticaba skin by SEM, we tested wax and calcium chloride applications for waterproofing the skin, in order to reduce both the dehydration of fruit as the air inlet to the pulp, which probably affect the fruit taste, which consumer calls "fermentation" (Figure 9).

The carnauba wax has been one of the most widely used coatings in fruit and vegetables. It is removed from the leaves and flowers buds of a palm tree (Copernicia cerifera Mart.), native to Brazil (LORENZI, 2002). In many fruit, wax is intended to provide gloss, decrease weight loss and maintain firmness for prolonged periods. It also guarantees a resistance of fruit to pathogens and extends the shelf life (JACOMINO et al., 2003). Calcium salts, such as calcium chloride, could increase the calcium levels in the fruit, strengthen cell walls and help to control disorders, by inhibiting the action of pectolytic enzymes, responsible for softening and deterioration (CYBULSKA; ZDUNEK; KONSTANKIEWICZ, 2011).

In this work, both control fruit and fruit coated with wax and calcium chloride lasted 7 days. The coating applications in fruit guaranteed the brightness, but did not reduce the loss of

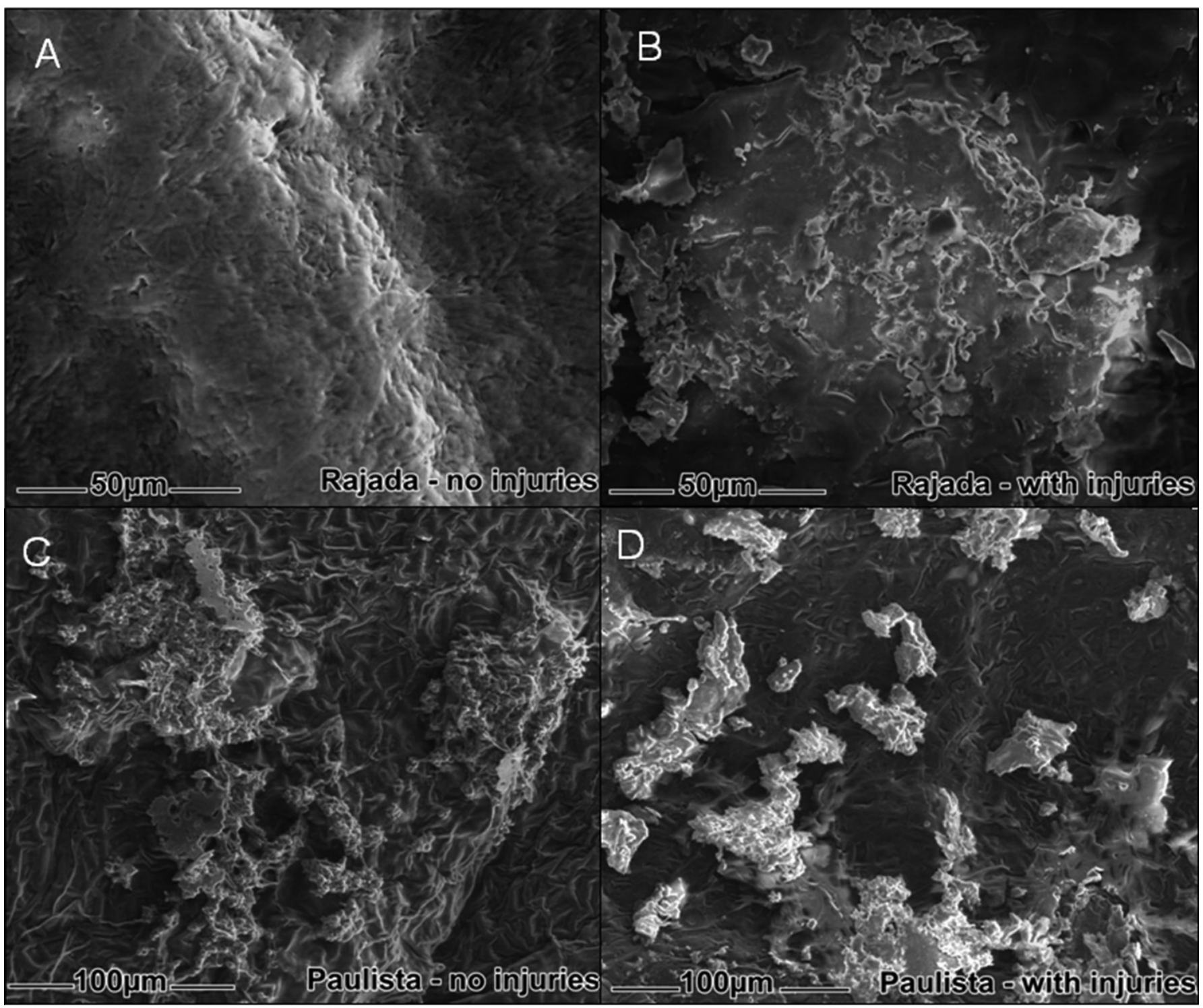

Figure 8. Micrographs of the surface Jaboticaba Rajada (A and B) and Paulista (C and D), with or without mechanical injury. 
weight, with no significant difference between treatments. We also observed that fruit without peduncle were more wilted than fruit that the peduncle was conserved at harvest procedure.

Figure 9 shows the surface of fruit visualized by SEM. It was observed upon the epidermis, gaps similar to stomata and the presence of wax. This combination could act in the regulation of water loss, providing protection to the surface and turgidity of the fruit (TAIZ; ZEIGER, 2009).
When the fruit was treated with water, this protective surface was removed and the stomata and the entire epidermis probably were exposed to physical and microbiological attacks (Figure 9A). The micrographs revealed that the surface treated with calcium chloride or wax was covered more densely than the natural fruit (Figure 9B and C), but we still need to know if this treatment is enough to extend the fruit shelf-life. The finding that jaboticaba skin has stomata opens a new perspective for future researches in the sense of improving their shelf life.

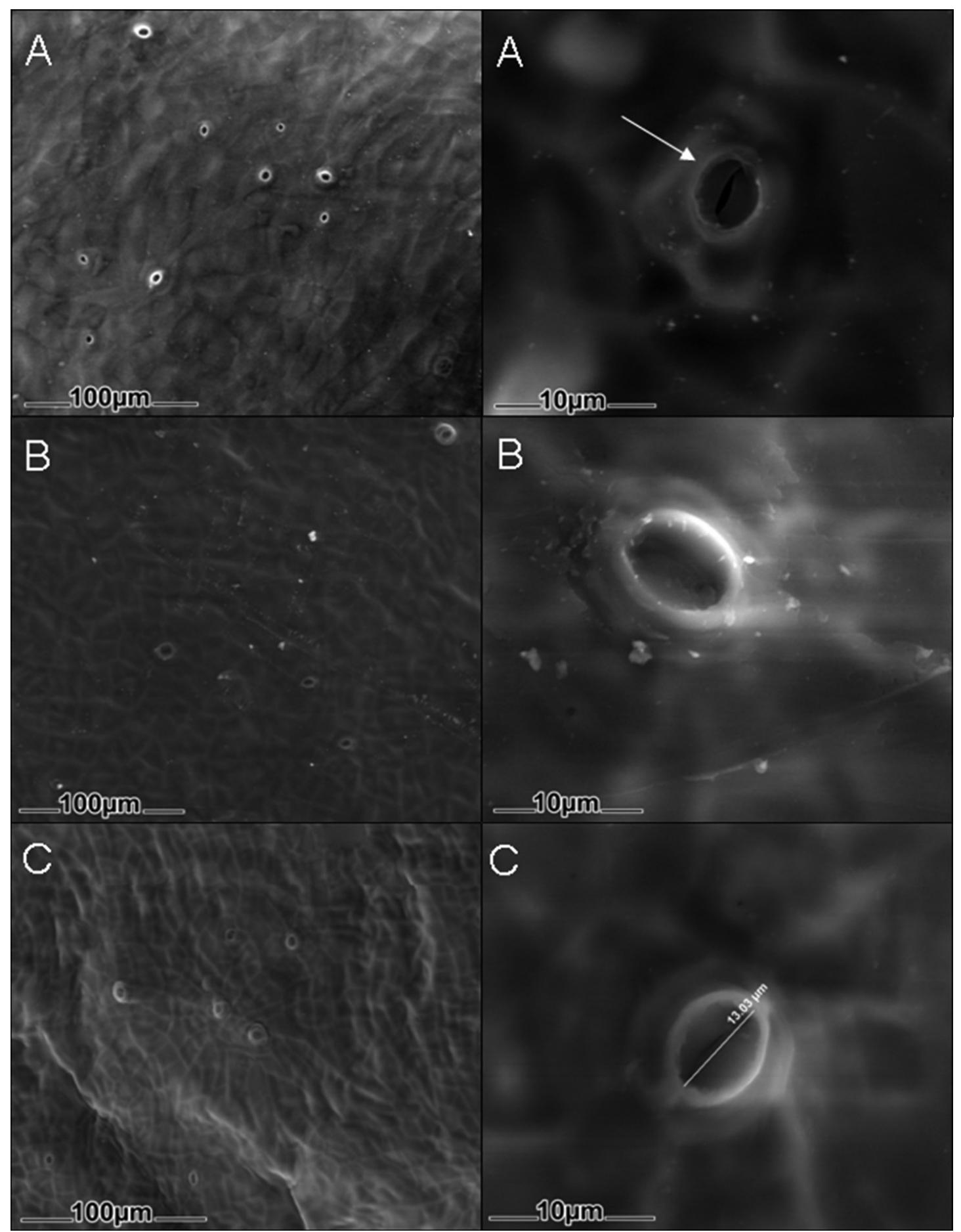

Figure 9. Micrographs of the surface Jaboticaba fruits, obtained from (A) control-fruit, fruits treated with carnauba wax $40 \%$ (B) and calcium chloride (C). The arrow indicates the presence of stomata-like structure on the surface of the shell. 


\section{Conclusions}

"Flower and fruit" thinning allowed fruit with higher quality as diameter, volume and mass. Non-thinned plants showed high yield, however fruit had low quality. Fruit of the thinning treatments lasted twice compared to control fruit, when maintained under chilling. Both the maintenance of soluble solids as the absence of volatile compounds formation during storage indicated that there was no natural fermentation of the jaboticaba pulp after harvest.

Potassium permanganate and treatments with wax and calcium did not extend the shelf life of jaboticaba. The stomatalike structures can be explored in the future, in order to prolong the jaboticaba shelf life.

\section{Acknowledgements}

We wish to acknowledge the engineer Paulo Hideo Higatti for providing fruit and Marcia Morais, Lucia Justino da Silva, Angélica dos Santos Carvalho, Alessandra A. Neves, and Dr Tania S. Shiga for technical assistance. We are grateful to CNPq for financial support and CAPES for scholarship.

\section{References}

AMORÓS, A. et al. Physico-chemical and physiological changes during fruit development and ripening of five loquat (Eriobotrya japonica Lindl.) cultivars. Food Science and Technology International, v. 9, n. 1, p. 43-49, 2003. http://dx.doi.org/10.1177/1082013203009001007

BARROS, R. S.; FINGER, F. L.; MAGALHÃES, M. M. Changes in nonstructural carbohydrates in developing fruit of Myrciaria jaboticaba. Scientia Horticulturae, v. 66, n. 3-4, p. 209-215, 1996. http://dx.doi. org/10.1016/S0304-4238(96)00910-7

BERNARDI, J.; HOFFMANN, A. Sistema de produção de pêssego de mesa na região da Serra Gaúcha. Embrapa Uva e Vinho, 2003. (Sistema de Produção, n. 3). Disponível em: <http:// sistemasdeproducao.cnptia.embrapa.br/FontesHTML/Pessego/ PessegodeMesaRegiaoSerraGaucha/conducao.htm\#raleio>.

BRACKMANN, A.; STEFFENS, C. A.; GIEHL, R. F. M. Armazenamento de pêssego 'Chimarrita' em atmosfera controlada e sob absorção de etileno. Ciência Rural, v. 33, n. 3, p. 431-435, 2003. http://dx.doi. org/10.1590/S0103-84782003000300006

CORDENUNSI, B. R. et al. Effects of temperature on the chemical composition and antioxidant activity of three strawberry cultivars. Food Chemistry, v. 91, n. 1, p. 113-12, 2005. http://dx.doi. org/10.1016/j.foodchem.2004.05.054

CYBULSKA, J.; ZDUNEK, A.; KONSTANKIEWICZ, K. Calcium effect on mechanical properties of model cell walls and apple tissue. Journal of Food Engineering, v. 102, n. 3, p. 217-223, 2011. http:// dx.doi.org/10.1016/j.jfoodeng.2010.08.019

DONADIO, L. C.; MÔRO, F. V.; SERVIDONE, A. A. Frutas Brasileiras. Jaboticabal: Ed. Novos Talentos, 2004. 248 p.

ESPINO-DÍAS, M. et al. Development and Characterization of Edible Films Based on Mucilage of Opuntia ficus-indica (L.). Journal of Food Science, v. 75, p. E347-E352, 2010. http://dx.doi.org/10.1111/ j.1750-3841.2010.01661.x

FALLAHI, E.; MOHAN, S. K. Influence of nitrogen and rootstock on tree growth, precocity, fruit quality, leaf mineral nutrients, and fire blight in Scarlet Gala apple. HortTechnology, v. 10, n. 3, p. 589596, 2000.
GOMES, F. P. Curso de estatística experimental. Piracicaba: USP/ ESALQ, 2000. 477 p.

HEHNEN, O. et al. Mechanical flower thinning improves fruit quality of apples and promotes consistent bearing. Scientia Horticulturae, v. 134, p. 241-244, 2012. http://dx.doi.org/10.1016/j. scienta.2011.11.011

JACOMINO, A. P. et al. Conservação de goiabas tratadas com emulsões de cera de carnaúba. Revista Brasileira de Fruticultura, v. 25 , n. 3, p. 401-405, 2003. http://dx.doi.org/10.1590/S010029452003000300010

JERONIMO, E. M. et al. Conservação pós-colheita de mangas 'Tommy Atkins' armazenadas sob atmosfera modificada. Semina: Ciências Agrárias, v. 28, n. 3, p. 417-426, 2007.

LORENZI, H. Brazilian Trees: A Guide to the Cultivation and Identification of Brazilian Trees, Vol.1. Nova Odessa, Plantarum, 2002.

MANICA, I. Frutas nativas, silvestres e exóticas 1 - técnicas de produção e mercado: abiu, amora preta, araçá, bacuri, biribá, carambola, cereja do rio grande e jaboticaba. Porto Alegre: Cinco Continentes, 2000. 327 p.

MONTES, C. et al. Application of tristimulus colorimetry to optimize the extraction of anthocyanins from jaboticaba (Myrciaria jaboticaba Berg.). Food Research International, v. 38, n. 8-9, p. 983-988, 2005.

OUMA, G. Fruit thinning with specific reference to citrus species: a review. Agriculture and Biology Journal of North America, v. 3, n. 4, p. 175-191, 2012.

PERIN, E. et al. Referência modular no 04 frutas de caroço: pêssego/ nectarina/ameixa. IAPAR, 2012. Disponível em: <http://www.iapar. br/arquivos/ File/zip_pdf/redereferencia/pp_modsudoestefruta. pdf $>$. Acesso em: 4 dez. 2012.

REYNERTSON, K. A. et al. Bioactive depsides and anthocyanins from jaboticaba (Myrciaria cauliflora). Journal of Natural Products, v. 69, n. 8, p. 1228-1230, 2006. http://dx.doi.org/10.1021/np0600999

SCHWABE, W. F. S. Wetting and temperature requirements for infection of mature apples by Venturia inaequalis in South Africa. Annals of Applied Biology, v. 100, p. 415-423, 1982. http://dx.doi. org/10.1111/j.1744-7348.1982.tb01408.x

SOARES, N. B. et al. Jaboticaba: instruções de cultivo. Porto Alegre: Cinco Continentes, 2001. 33 p.

SOUZA FILHO, M. F.; COSTA, V. A. Manejo integrado de pragas da goiabeira. In: ROZANE, D. E.; COUTO, F. A. C. Cultura da goiabeira: tecnologia e mercado. Viçosa:Empresa Júnior de Agronomia, 2003. p. 177-206.

TAIZ, L.; ZEIGER, E. Fisiologia Vegetal. Porto Alegre: Artmed, 2009. $286 \mathrm{p}$.

TONIETTO, A. et al. Raleio de Frutas retiradas de ramos ladrões. Pelotas: Ed. UFPel, 2000. (Booklet).

UNIVERSIDADE DE SÃO PAULO. Faculdade de Ciências Farmacêuticas. Departamento de Alimentos e Nutrição Experimental. Tabela Brasileira de Composição de Alimentos. USP, 1998. versão 5.0. Disponível em: <http://www.fcf.usp.br/ tabela>.

VARGAS, M. et al. Recent advances in edible coatings for fresh and minimally processed fruits. Critical Reviews in Food Science and Nutrition, v. 48, n. 6, p. 496-511, 2008. http://dx.doi. org/10.1080/10408390701537344

ZAGORY, D. Ethylene-removing packaging. In: ROONEY, M. L. Active food packaging. Glasgow: Chapman \& Hall, 1995. p. 38-54. 